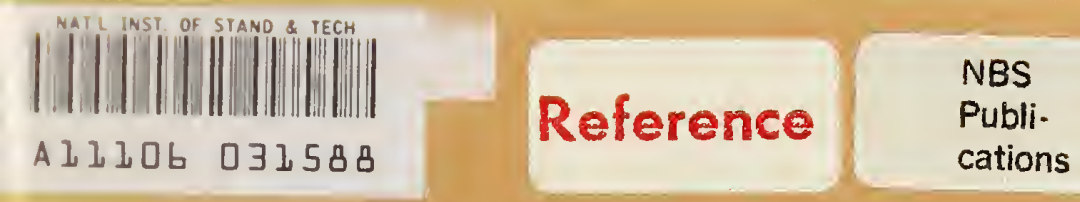

\title{
NBSIR 84-2834
}

\section{Construction Research in Japan}

H. S. Lew

U.S. DEPARTMENT OF COMMERCE

National Bureau of Standards

National Engineering Laboratory

Center for Building Technology

Structures Division

Gaithersburg, Maryland 20899

September 1984

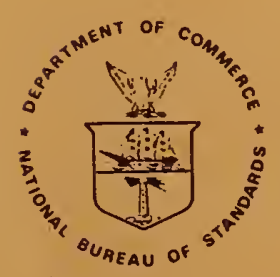

U.S. DEPARTMENT OF COMMERCE

NATIONAL BUREAU OF STANDARDS

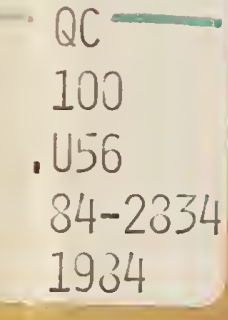



NBSIR 84-2834

CONSTRUCTION RESEARCH IN JAPAN

H. S. Lew

U.S. DEPARTMENT OF COMMERCE

National Bureau of Standards

National Engineering Laboratory

Center for Building Technology

Structures Division

Gaithersburg, Maryland 20899

September 1984

U.S. DEPARTMENT OF COMMERCE, Malcolm Baldrige, Secrotary

NATIONAL BUREAU OF STANDARDS. Emeot Ambler. Diroctor 



\section{PREFACE}

The writer has had a number of opportunities to visit Japanduring the past several years. He has visited many major government research facilities and university laboratories. In October 1981, he visited several large construction firms where significant $R$ \& D efforts are being carried out to develop new construction technologies. Some of the technical and statistical information on Japan's construction industry was obtained from the Library of the U.S. Embassy in Tokyo and the Public Works Research Institute (PWRI), Ministry of Construction, Government of Japan. The visits to construction firms were arranged by Dr. Tadayoshi Okubo, Director-General of the PWRI. His assistance and those managers and researchers who gave generously their time for meetings are gratefully acknowledged. 
The construction industry is one of the key industries in Japan. The annual volume of business of the industry accounts for over 20 percent of the GNP of Japan. Partially due to large investments in the public works projects by the Japanese Government, the industry maintained a steady growth during the past two decades. During this period of steady growth, many large construction firms established research laboratories to place themselves in a favorable position in the domestic, as well as international, construction market.

The construction machinery industry of Japan also grew steadily during the same period, and their share of the world market increased significantly. In order to meet foreign competition, the industry has also made significant investments in their $R \& D$ efforts.

This report examines the $R \& D$ efforts of Japan's construction and construction machinery industries and their trends.

Keywords: Construction; construction machinery; Japan; laboratories; research; $R \& D$. 
PREFACE $\ldots \ldots \ldots \ldots \ldots \ldots \ldots \ldots \ldots \ldots \ldots \ldots \ldots \ldots \ldots \ldots \ldots \ldots \ldots \ldots \ldots \ldots \ldots \ldots \ldots \ldots \ldots \ldots$

ABSTRACT $\ldots \ldots \ldots \ldots \ldots \ldots \ldots \ldots \ldots \ldots \ldots \ldots \ldots \ldots \ldots \ldots \ldots \ldots \ldots \ldots \ldots \ldots \ldots \ldots$ iv

LIST OF FIGURES $\ldots \ldots \ldots \ldots \ldots \ldots \ldots \ldots \ldots \ldots \ldots \ldots \ldots \ldots \ldots \ldots \ldots \ldots \ldots \ldots \ldots \ldots$

LIST OF TABLES ...................................... vi

1. INTRODUCTION $\ldots \ldots \ldots \ldots \ldots \ldots \ldots \ldots \ldots \ldots \ldots \ldots \ldots \ldots \ldots \ldots \ldots \ldots \ldots \ldots \ldots \ldots \ldots \ldots$

2. HISTORICAL OVERVIEW ................................. 2

a Early Construction Technology ......................... 2

b. Imported Technology ................................ 2

c. Advances in Technological Developments in Construction ....... 3

3. CONSTRUCTION INDUSTRY TRENDS $\ldots \ldots \ldots \ldots \ldots \ldots \ldots \ldots \ldots \ldots \ldots \ldots \ldots \ldots \ldots \ldots \ldots \ldots$

4. CONSTRUCTION $R \& D \ldots \ldots \ldots \ldots \ldots \ldots \ldots \ldots \ldots \ldots \ldots \ldots \ldots \ldots \ldots \ldots \ldots \ldots \ldots \ldots$

5. CONSTRUCTION EQUIPMENT INDUSTRY ......................... 15

6. CONCLUSIONS ...................................... 17

7. REFERENCES .......................................... 19 


\section{LIST OF FIGURES}

$\underline{\text { Page }}$

1. FOREIGN CONSTRUCTION CONTRACTS WON BY JAPANESE FIRMS $\ldots \ldots \ldots \ldots \ldots 6$

2. LAYOUT OF RESEARCH LABORATORIES OF KAJIMA INSTITUTE OF

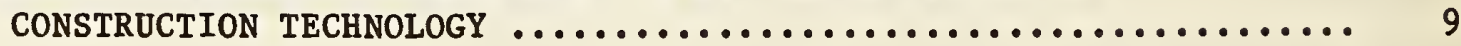

3. ORGANIZATION OF THE PUBLIC WORKS RESEARCH INSTITUTE $\ldots \ldots \ldots \ldots \ldots . . .12$

4. ORGANIZATIONAL STRUCTURE OF THE BUILDING RESEARCH INSTITUTE $\ldots \ldots \ldots 13$

LIST OF TABLES

1. MAIN CONSTRUCTION COMPANY RESEARCH INSTITUTES ............... 8 


\section{INTRODUCTION}

At the end of World War II in 1945, Japan had suffered near total destruction of its industrial complexes and over 40 percent of its urban areas destroyed from the bombing. It was estimated that over 4 million dwelling units were needed throughout Japan at that time. During the recovery period, most construction companies which survived the war were engaged in reconstruction activities, particularly in construction of dwelling units to meet the immediate need of sheltering of millions of urban populace.

With a steady and phenomenal growth of economy in Japan during the 1960's and early 1970's, the construction industry expanded rapidly in both building and public works areas. The industry made a significant stride in developing innovative contruction methods for building as well as underground construction. Today, the technological level of Japan's construction industry is considered to be among the highest in the world. Much of the technological developments have been carried out by Japan's large construction firms (about 20) through their research and development (R \& D) establishments.

In this report, Japan's construction industry and its $R$ \& $D$ efforts are reviewed and its trend examined. Much of the material for this report was obtained during meetings with employees of $R$ \& D laboratories of large construction companies, government research institutions, and university laboratories. 


\section{HISTORICAL OVERVIEW}

\section{a. Early Construction Technology}

Throughout its history, Japan has shown an aptitude for the assimilation of foreign ideas and the adaption of foreign techniques to its own tradition. As early as the third century, Japan was strongly influenced by the continental culture of China and Korea. In later years, the Japanese stopped copying continental models and developed their own models. The existence of dual models can be seen at surviving temples, where both continental influences and distinct Japanese forms of architecture are evident.

Because rice grown in wet paddies has long been the staple of their diet, the Japanese have historically placed great importance on controlling water. From ancient times, construction of irrigation and drainage facilities, land filling, and water use and control have been vitally important. The results of extensive Japanese experience in these areas can be seen today in construction, dredging and land reclamation.

\section{b. Imported Technology}

The influence of Western technology surged into Japan after the collapse of the Shogunate and the Meiji Restoration in 1867. At that time, Japan used the West as a model for modernization of its economy, industry and society in general. With this influx came the latest construction technologies. Railroads were built with English technical guidance, river and harbor works were carried out with technologies developed in France and Holland, and waterworks and sewerage systems were constructed with U.S. technology.

Brick and stone masonry was introduced in Western-style building construction, primarily for public buildings. Steel-frame and reinforced-concrete 
construction were imported at the end of the nineteenth and beginning of the twentieth centuries. As a result of the Great Kanto Earthquake of 1923, which destroyed much of Tokyo and surrounding areas, Japanese construction technology developed especially in the direction of seismic resistant structures. By the 1930's Japanese construction technology had caught up with that of the Western countries [1].

\section{c. Advances in Technological Development in Construction}

Real advances in modern construction technology came only after World War II. Faced with near devastation of industrial complexes and urban areas of large cities, Japan began to apply available technologies, domestic and foreign, in reconstruction efforts.

During the high economic growth period of the $1960^{\prime}$ s and early 1970 's, the construction industry flourished both in housing construction and in national land development projects. In the public works area, highway construction led the volume of the civil engineering projects followed by harbor works, 1 and reclamation and railway construction, including the Shinkansen super express railway [1]. Japan had made significant advances in developing new contruction technologies out of the sheer necessity of meeting the demands of rapidly expanding domestic construction projects. For example, through laboratory research, Japan made significant advances in the seismic resistance design of buildings and bridges, underground construction techniques, and construction methods for offshore structures. 


\section{CONSTRUCTION INDUSTRY TRENDS}

The annual construction investment in Japan exceeded $\$ 200$ bi 11 ion in 1980 accounting for more than 20 percent of Japan's GNP [2]. This was a significantly greater percentage of the GNP than that of the U.S. U.S. construction investment in 1980 was $\$ 229$ billion [3] which amounted to about 9 percent of the U.S. GNP. Recognizing the importance of the construction industry in the overall economy, the Japanese government deliberately made large investments in public works projects during the 1970's despite economic setbacks due to oil crises in 1973 and 1977. As a result, the construction industry maintained a steady annual growth of 11 to 13 percent. Since 1980, however, there has been no increase in public spending by the Japanese government, and the rate of increase slumped to only 5 percent.

To recover from the depressed construction market, large construction companies have directed their $R \& D$ efforts to the development of new types of structures which are expected to have an increased market demand in the future. Large construction firms, particularly the five largest firms Kajima Corp., Taisei Corp., Shimizu Ltd., Ohbayashi-Gumi Ltd., and Takenaka Komuten - are now competing to gain a large share of energy-related facility construction such as nuclear power plants and inground LNG tank construction. Since the design and construction of these structures required advanced civil engineering technologies, construction firms made substantial investments in their $R \& D$ efforts to capture a share of this market.

While the domestic construction market has experienced sluggish growth in recent years, the overseas Japanese construction market has been growing steadily. 
A survey of the Overseas Construction Association of Japan (figure 1) showed that foreign contracts awarded to its 58 member firms amounted to $¥ 537$ billion ( $\$ 2.25$ billion) in 1979 [5]. However, this is still about only 1 percent of domestic construction investment. Construction projects in the Middle East accounted for about 56.5 percent of the total revenue of overseas activities [6], followed by construction projects in Southeast Asia which accounted for about 35 percent. The remaining percentages included construction projects on the South and North American continents.

Because of advanced construction methods developed in many of their domestic projects, Japanese construction firms have successfully out performed stiff American and European competition. Japanese firms even began to penetrate the U.S. market. It was thought that foreign contractors could not successfully compete in the highly competitive and complex construction market in the U.S. However, for example, using the earth pressure balance shield tunneling system, Japan's fourth largest contractor Ohbayashi-Gumi Ltd., has won three tunneling contracts in recent years, one municipal government project and two Federal government projects, for a total value of $\$ 45.5$ million. On one project, Ohbayashi-Gumi not only completed the project with a net profit, the firm also finished ahead of schedule at a $\$ 3.87$ million savings to U.S. taxpayers.

The Overseas Construction Association of Japan projects that overseas activities of their member firms will increase in the years ahead. Advanced knowledge and know-how in construction methods will allow Japanese firms to participate in the area of underground tunneling construction, in the construction of offshore structures and in mass transit rail system contruction. 


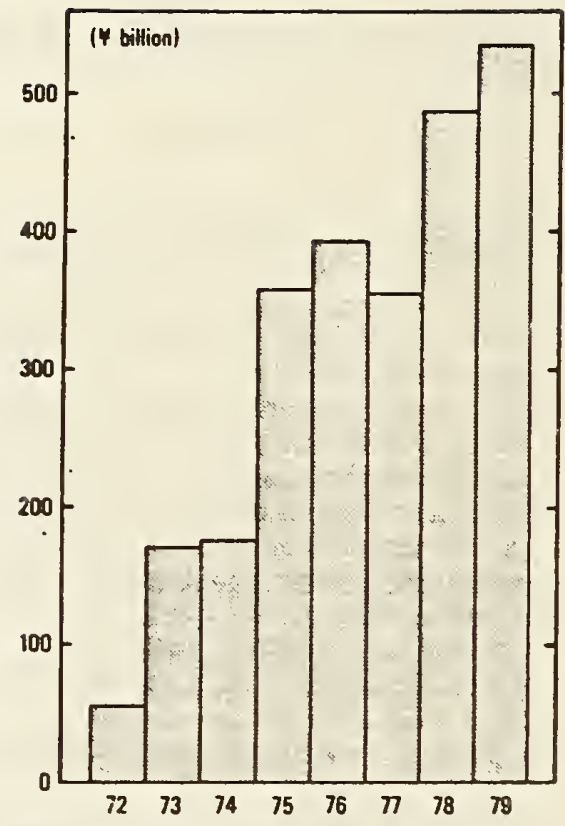

Source: Overseas Construction Association of Japan, Inc.

Figure 1. Foreign Construction Contracts Won by Japanese Firms 
4. CONSTRUCTION RESEARCH AND DEVELOPMENT

In 1980, about $\$ 120$ million was spent on $R$ \& $D$ by private Japanese construction firms and about $\$ 60$ million was spent by government and university laboratories. These $R \& D$ expenditures were about 0.1 percent of the 1980 construction cost [3].

Much of the $R$ \& $D$ effort in construction technology is carried out by large private firms. These large construction firms, in most cases, handle all phases of construction, from site planning and engineering design to actual constuction. They maintain research laboratories especially dedicated to solving problems at hand and developing strategies for meeting future market demands. Most of the major laboratories are listed in Table 1. For example, Kajima Corporation maintains a large research complex known as Kajima Institute of Construction Technology which has a research staff of about 220, many of whom have received training in the U.S. Figure 2 shows a general layout of this research complex. The laboratories include such testing facilities as a biaxial earthquake simulator, large structural testing fixtures, 58 m long wave basin, boundary layer wind tunnel, anechoic chamber, and other unique testing facilities. There is no single U.S. civil engineering institution (public or private) which has facilities equal to the ones at the Rajima Institute.

The types of research carried out by these firms can broadly be classified into three categories [7].

(a) Problems that arise from ongoing construction activities which require near-term solutions, 



\begin{tabular}{|c|c|c|c|c|c|c|c|c|}
\hline $\begin{array}{l}\text { Company } \\
\text { naine } \\
\text { (1) } \\
\end{array}$ & $\begin{array}{l}1980 \\
\text { capital in } \\
\text { millions of } \\
\text { yen } \\
\text { (2) }\end{array}$ & $\begin{array}{c}\text { Location of } \\
\text { institute } \\
\text { (3) }\end{array}$ & $\begin{array}{c}\text { Date } \\
\text { establ i shed } \\
(4) \\
\end{array}$ & $\begin{array}{c}\text { Land area, } \\
\text { in square } \\
\text { meters } \\
(5)\end{array}$ & $\begin{array}{c}\text { Building area in } \\
\text { square meters } \\
(6)\end{array}$ & $\begin{array}{c}\text { Staff } \\
(7)\end{array}$ & $\begin{array}{l}\text { Researchers } \\
\text { (8) }\end{array}$ & $\begin{array}{c}1980 \text { budget } \\
\text { in millions } \\
\text { of yen } \\
(9)\end{array}$ \\
\hline $\begin{array}{l}\text { Ohbayashi } \\
\text { Gunii, } \\
\text { Ltd. }\end{array}$ & 24,460 & Tokyo & 1945 & 75,543 & 8,739 & 194 & 110 & 1,290 \\
\hline $\begin{array}{l}\text { Shimizu } \\
\text { Const. } \\
\text { Co., itd. }\end{array}$ & 27,500 & Tokyo & 1946 & 28,997 & 15,182 & 214 & 128 & 1,750 \\
\hline $\begin{array}{l}\text { Taisei } \\
\text { Corpora- } \\
\text { tion }\end{array}$ & 38,600 & Tokyo & 1958 & 34,822 & 12,439 & 166 & 109 & 1,500 \\
\hline $\begin{array}{l}\text { Kajima } \\
\text { Corpora- } \\
\text { tion }\end{array}$ & 36,300 & Tokyo & 1949 & 23,577 & 20,406 & 362 & 210 & 2,648 \\
\hline $\begin{array}{l}\text { Takenaka } \\
\text { Komuten } \\
\text { Co., Ltd. }\end{array}$ & 50,000 & Tokyo & 1959 & 11,066 & 12,097 & 251 & 185 & 1,850 \\
\hline $\begin{array}{l}\text { Kumagai- } \\
\text { Gumi, Ltd. }\end{array}$ & 14,520 & Tokyo & 1962 & ---.- & 400 & 180 & 150 & 870 \\
\hline $\begin{array}{l}\text { Hazama-Gumi, } \\
\text { Ltd. }\end{array}$ & 10,000 & Tokyo & 1945 & 2,600 & 4,038 & 84 & 80 & 1,528 \\
\hline $\begin{array}{l}\text { Toda Con- } \\
\text { struction } \\
\text { Co., Ltd. }\end{array}$ & 7,500 & $\begin{array}{l}\text { Matsudo, } \\
\text { Chiba }\end{array}$ & 1958 & 5,360 & 1,550 & 65 & 30 & 513 \\
\hline $\begin{array}{l}\text { Nishimatsu } \\
\text { Const. } \\
\text { Co., Ltd. }\end{array}$ & 15,800 & $\begin{array}{l}\text { Yamato, } \\
\text { Kanagawa }\end{array}$ & 1955 & 7,062 & 843 & 24 & 20 & 160 \\
\hline $\begin{array}{l}\text { Fujita } \\
\text { Corpora- } \\
\text { tion }\end{array}$ & 6,160 & $\begin{array}{l}\text { Yokomhama, } \\
\text { Kanagawa }\end{array}$ & 1970 & 12,427 & 2,737 & 128 & 05 & 1,020 \\
\hline $\begin{array}{l}\text { Okumura } \\
\text { Const. } \\
\text { Co., itd. }\end{array}$ & 15,800 & Osaka & 1964 & 2,400 & 2,300 & 73 & 62 & 665 \\
\hline $\begin{array}{l}\text { Maeda } \\
\text { Const. } \\
\text { Co., itd. }\end{array}$ & 5,060 & Tokyo & 1963 & 6,200 & 3,077 & 107 & 98 & 800 \\
\hline $\begin{array}{l}\text { Sato Kogyo } \\
\text { Co., Ltd. }\end{array}$ & 6,913 & $\begin{array}{l}\text { Atsugi, } \\
\text { Kanagawa }\end{array}$ & 1963 & 7,000 & 2,500 & 65 & 55 & 395 \\
\hline $\begin{array}{l}\text { Mitsui } \\
\text { Co., Ltd }\end{array}$ & 6,050 & Tokyo & 1967 & 8,210 & 2,582 & 53 & 36 & 1,087 \\
\hline $\begin{array}{l}\text { Penta-Ocean } \\
\text { Const. } \\
\text { Co., Ltd. }\end{array}$ & 14,072 & Yokohama & 1967 & 3,139 & 2,175 & 60 & -..- & 400 \\
\hline $\begin{array}{l}\text { Toa Harbor } \\
\text { Works Co., } \\
\text { Ltd }\end{array}$ & 8,860 & Yokohama & 1970 & 420 & 1,200 & 55 & 48 & 530 \\
\hline $\begin{array}{c}\text { Tokyu Const. } \\
\text { Co., Ltd. }\end{array}$ & 6,259 & $\begin{array}{l}\text { Kawasaki, } \\
\text { Kanagawa }\end{array}$ & 1968 & 2,044 & 1,088 & 47 & 37 & 272 \\
\hline $\begin{array}{l}\text { The Nippon } \\
\text { Road Co., } \\
\text { Ltd. }\end{array}$ & 3,300 & Tokyo & 1958 & 3,329 & 1,772 & 51 & 40 & 1698 \\
\hline $\begin{array}{l}\text { Aok i Const. } \\
\text { Co., Ltd. }\end{array}$ & 5,815 & Tokyo & 1959 & 7,000 & 1,000 & 40 & 35 & -- - \\
\hline $\begin{array}{l}\text { Konoike } \\
\text { Const. } \\
\text { Co., Ltd. }\end{array}$ & 5,000 & Osaka & 1963 & 6,000 & 1,500 & 46 & 80 & 270 \\
\hline $\begin{array}{l}\text { Japan Gaso- } \\
\text { line Co., } \\
\text { Ltd. }\end{array}$ & 2,154 & Yokohama & 1960 & 23,500 & 9,190 & 178 & 147 & ins \\
\hline
\end{tabular}


Table 1. (Continued)

\begin{tabular}{|c|c|c|c|c|c|c|c|c|}
\hline (1) & (2) & (3) & (4) & (5) & (6) & (7) & (8) & (9) \\
\hline $\begin{array}{l}\text { Nippon Koei } \\
\text { Co., Ltd. }\end{array}$ & 1,958 & $\begin{array}{l}\text { Higashima- } \\
\text { tsuyama, } \\
\text { Saitama }\end{array}$ & 1960 & 27,400 & 1,500 & 50 & 35 & 400 \\
\hline $\begin{array}{l}\text { Ohbayashi } \\
\text { Road } \\
\text { Const. } \\
\text { Co., Ltd. }\end{array}$ & 1,200 & $\begin{array}{l}\text { Urawa, } \\
\text { Saitama }\end{array}$ & 1975 & 18,150 & 480 & 23 & 20 & $38 a$ \\
\hline $\begin{array}{l}\text { Taisei Road } \\
\text { Construc- } \\
\text { tion }\end{array}$ & 3,388 & $\begin{array}{l}\text { Urawa, } \\
\text { Sa itama }\end{array}$ & 1971 & 9,057 & 2,542 & 51 & 45 & 241 \\
\hline $\begin{array}{l}\text { Zenitaka } \\
\text { Corp. }\end{array}$ & 3,675 & Tokyo & 1976 & 24,888 & 1,025 & 33 & 28 & 257 \\
\hline $\begin{array}{l}\text { Nippon } \\
\text { Tetrapod } \\
\text { Co., Ltd. }\end{array}$ & 1,156 & $\begin{array}{l}\text { Tsuchiura, } \\
\text { Iharaki }\end{array}$ & 1968 & 24,257 & 6,974 & 68 & 53 & 89 \\
\hline $\begin{array}{l}\text { Toyo Const. } \\
\text { Co., Ltd. }\end{array}$ & 8,173 & Tokyo & 1976 & 2,640 & 605 & 12 & 8 & 85 \\
\hline $\begin{array}{l}\text { Maeda Road } \\
\text { Const. Co. }\end{array}$ & 3,190 & Tokyo & 1965 & 7,970 & 1,830 & 20 & 17 & 126 \\
\hline $\begin{array}{l}\text { Japan } \\
\text { Develop. } \\
\text { Co. }\end{array}$ & 4,100 & Tokyo & 1970 & 4,800 & 773 & 33 & 29 & 250 \\
\hline $\begin{array}{l}\text { Mi sawa Howes } \\
\text { Co. }\end{array}$ & 2,094 & Tokyo & 1973 & 3,139 & 9,241 & 84 & 78 & 968 \\
\hline $\begin{array}{l}\text { Raito Kogyo } \\
\text { Co. }\end{array}$ & 2,145 & $\begin{array}{l}\text { Funahashi, } \\
\text { Chiba }\end{array}$ & 1973 & 1,853 & 1,492 & 28 & 21 & 158 \\
\hline
\end{tabular}

a budget in 1974 . 


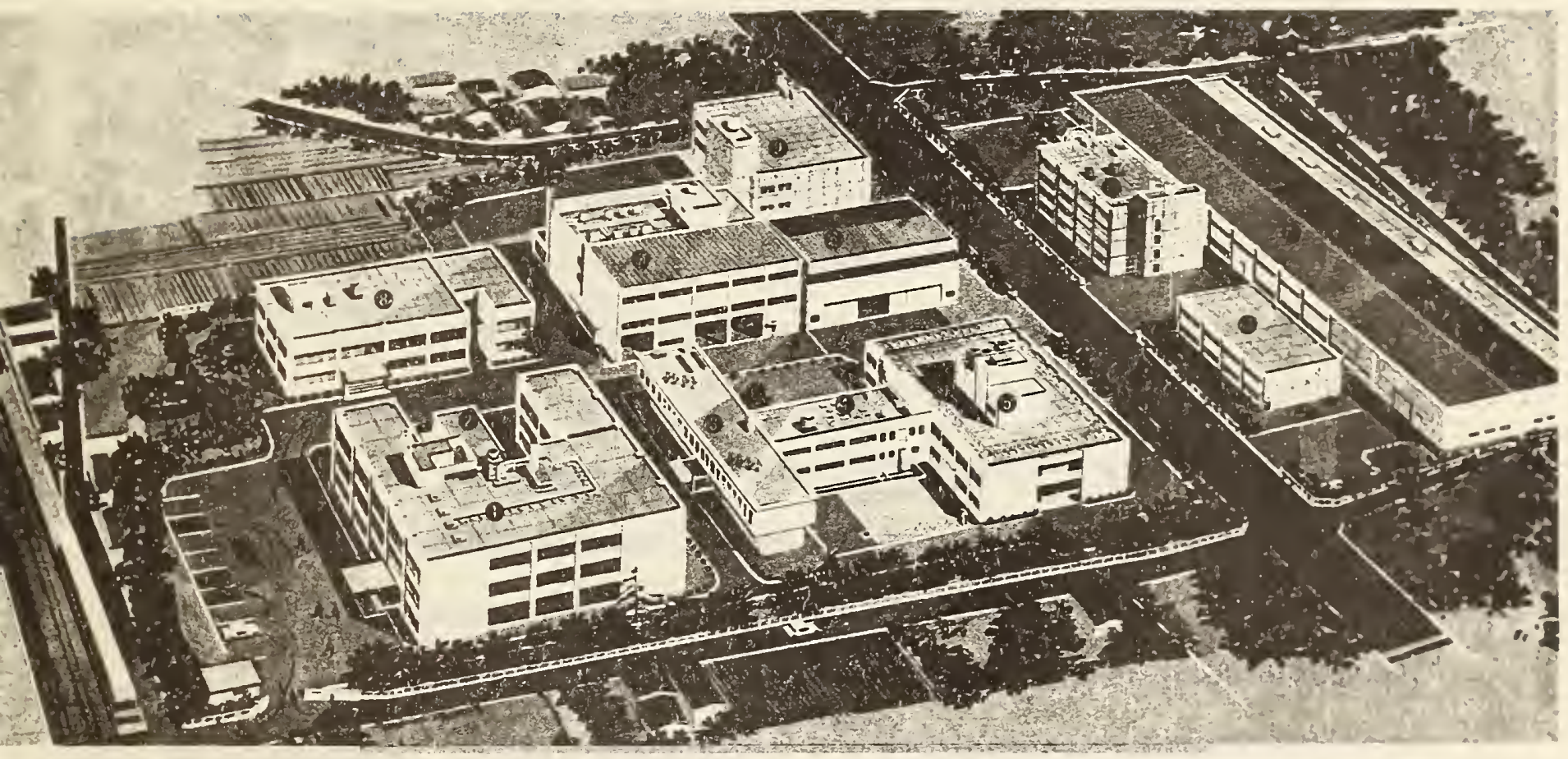

Total Site Area - 23,577 $\mathrm{m}^{2}$

Total Floor Area of Buildings - $20,406 \mathrm{~m}^{2}$

- Head Office, Building Eng. Dept., and Mechanical Eng. Dept.

(2) Radio Isotope Lab.

(3) (5). 9 ( ) (1)

Geotechnical Lab., Materials Lab., Environmental Eng. Lab., (6) 7

Large Structure Testing Laboratories.

(8) Civil Eng. Dept.

(12) Hydraulics Lab.

Figure 2 Layout of Research Laboratorles of Kajima Institute of Construction Technology 
(b) applied research to develop new technologies to increase future competitiveness in domestic and overseas market, and

(c) basic research which may not bring immediate pay-offs but may provide the firm with a competitive edge in future construction projects.

A significant amount of effort is spent on category (b). For example, the big five - Kajima, Taisei, Shimizu, Ohbayashi-Gumi and Takenaka Komuten - each independently carried out research on structural performance of nuclear containment structures subjected to earthquakes having magnitudes of 6-7. Today, the big five virtually monopolize the market for nuclear reactor containment construction. The knowledge gained from this research also enabled them to dominate in the design and contruction of most of the highrise structures in Japan. Research in the slurry-wal1 construction method by Kajima, Shimizu and Ohbayashi-Gumi gave them a competitive edge in getting a Tokyo Gas Company contract to build the world's largest underground LNG tank having a capacity of 130,000 liters.

National government laboratories carry out both basic and applied research programs primarily designed to support national policies and public welfare. Government laboratories also carry out testing and special projects to solve specific problems of other branches of the national government, prefectural governments and public corporations such as the Japan Highway Corporation and the Japan Housing Corporation.

Much of the governmental, construction-related research is carried out at the Public Works Research Institute (PWRI) and the Building Reseach Institute (BRI) of the Ministry of Construction, and to a lesser extent at the National 
Research Center for Disaster Prevention (NRCDP) of the Science and Technclogy Agency. These research organizations are all located in Tsukuba Science City, about $60 \mathrm{~km}$ to the northeast of Tokyo.

Both PWRI and BRI have extensive research facilities. The 1981 research budget for these two institutes was $\$ 38.2$ million $(\$ 32.8$ million for PWRI and $\$ 5.4$ million for BRI) which does not include the salary for employees. The salary is treated as a separate budget item which is not included in the research budget [4]. The organization charts of these two institutes describe their functions (figures 3 and 4 ).

The PWRI is the national center for civil engineering and deals with problems related to rivers, dam construction, erosion control, waste water treatment, construction methods and equipment, highways and structural engineering. The institute has a research staff of 310 and 48 buildings which house research laboratories and administrative offices. The institute has a large variety of testing facilities for materials, structures, soils, structural dynamics, aerodynamics, hydraulics and water quality.

The BRI has a research staff of 121 and 20 buildings. BRI's research complex includes a large structures laboratory where full-scale buildings up to eight stories can be tested under horizontal static and dynamic loads; a full-scale fire test facility; a building elements laboratory; a building materials laboratory; an environmental research laboratory; a wind and rain testing facility and a geotechnical laboratory.

The NRCDP has an annual budget of about $\$ 10$ million (1980). It has testing facilities to deal with earthquake and snow load effects on structures, landslide, runoff, tsunami and storm surge. At the present time, it has the second largest operating shaking table $(15 \mathrm{~m} \times 15 \mathrm{~m})$ in Japan. 


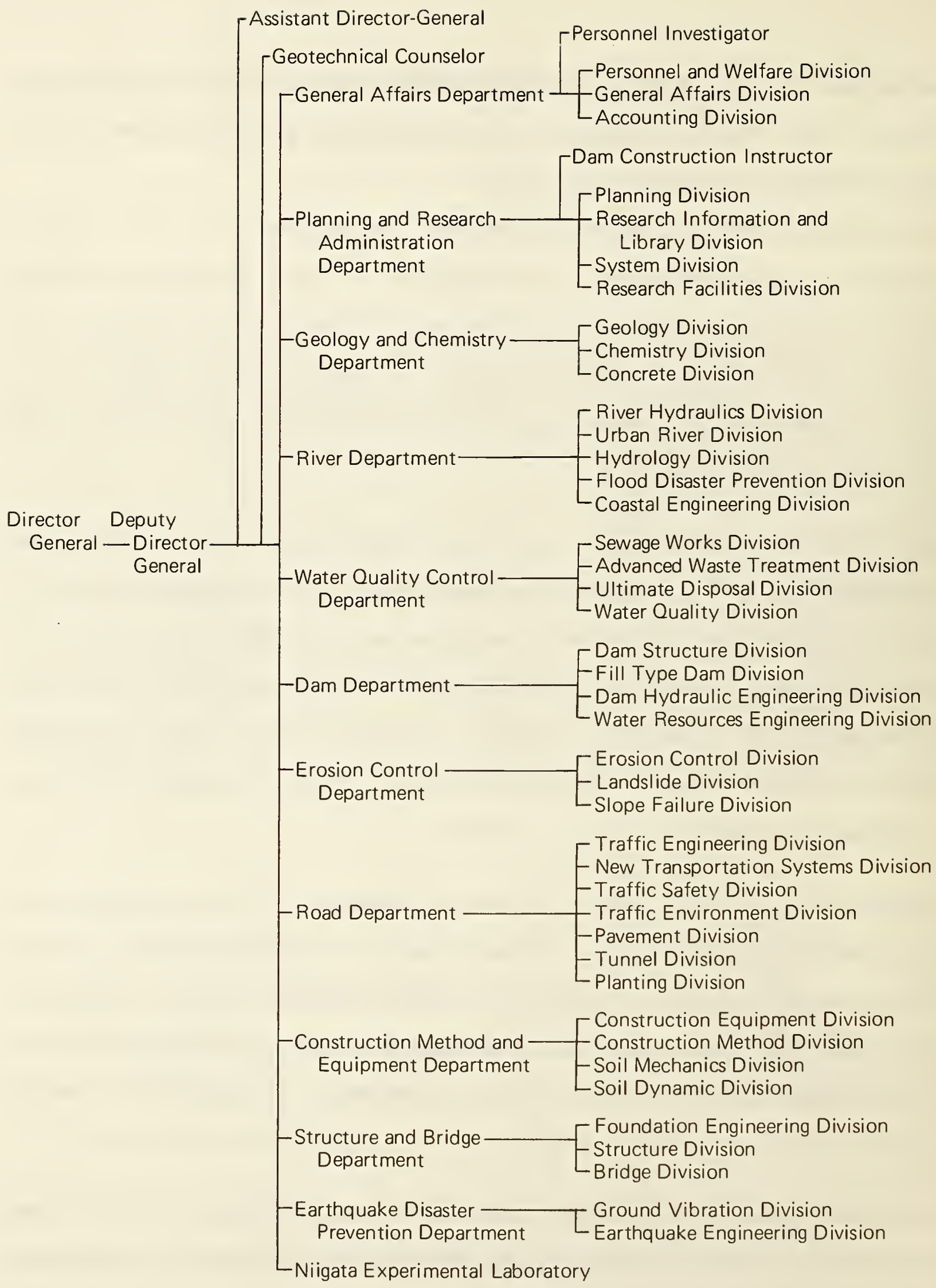

Figure 3 Organizational Chart of the Public Works Research Institute, Ministry of Construction 


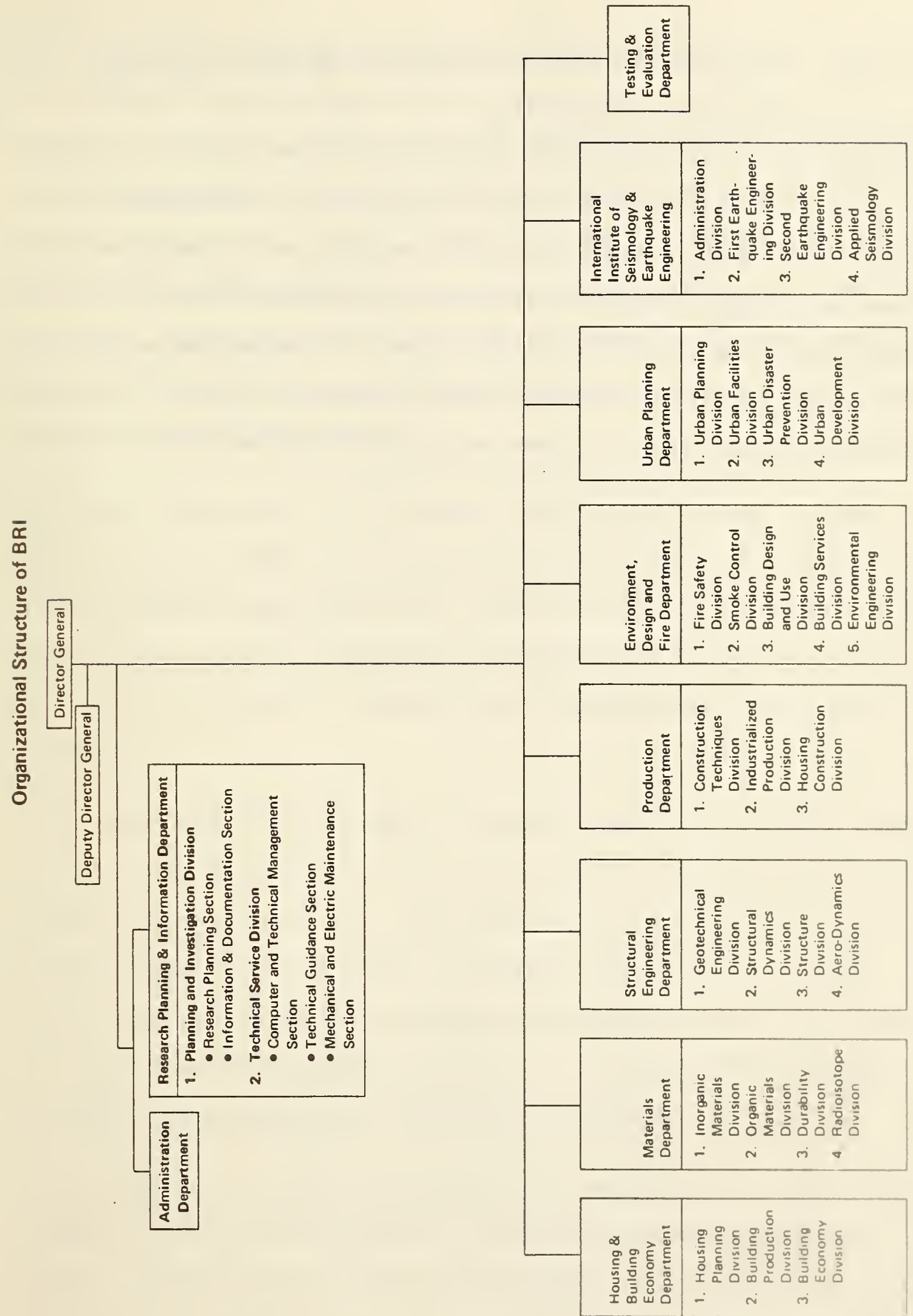

Figure 4 Organizational Chart of the Building Research Institute, Ministry of Construction 
University laboratories are supported mainly by funds provided by the national government (Ministry of Education). Their research efforts are primarily aimed at solving generic problems related to construction. Laboratory facilities of many of the national universities, including Tokyo, Kyoto, Osaka, Tohoku, Nogoyo, Tsukuba, and Tokyo Metropolitan University are not as extensive as those laboratories of national government institutes and large construction firms. While some universities have unique testing facilities such as wind tunnels at Tokyo and Kyoto Universities, by and large, most university laboratories do not have the most up-to-date equipment. 
Japan's construction equipment industry grew steadily during the period of high economic growth since 1955. Although it experienced a slump right after the oil crisis of 1973 , the total output reached $¥ 1,197$ billion (\$5 billion) in 1981 [3], and the industry is now regarded as one of the major industries in Japan. Bxports account for about 30-40 percent of the total production volume [5]. However, the percentage of export is expected to increase as domestic demands remsin constant.

We 11 over 200 construction equipment manufacturers compete to expand their share in export markets including Romatsu Ltd., ranked as the world's second largest equipment manufacturer after Caterpillar Tractor Co. Exports include almost every type of construction equipment from hydraulic excavators, bulldozers, and cranes to foundation work equipment and road construction machinery.

In the beginning, the development of Japan's construction equipment industry depended upon technologies obtained from western countries. In addition, Japanese manufacturers had linked themselves with western European and American manufacturers for capital investment and technical support. This link also gave Japanese manufacturers opportunities to export their products. At the present time, Japanese construction equipment is highly competitive with those manufactured by $\mathrm{U} . \mathrm{S}$. and European companies.

Most of the Japanese domestic demands for construction equipment depends largely on the level of activity in the domestic construction industry. For example, during periods of high economic growth, large engineering projects such as new town and highway construction demanded heavg constuction 
equipment such as bulldozers, hydraulic excavators and cranes. With a recent change in public works spending (since 1980) from large-scale new construction to readjustment of the 1 iving environment such as improvements in sewers, roads and sanitation facilities, the demand for hydraulic shovels has increased while the demand for heavy equipment has declined.

In order to offset the decline in domestic sales, Japanese manufacturers have exparded their efforts to obtain foreign sales. To improve their export position by removing territory restrictions, a number of large Japanese manufacturers have cut their ties to foreign firms such as Bucyrus-Erie Co. and Koehring Co. in the U.S. and Yumbo S.A. of France.

Japan's construction equipment industry expects to capture a significant part of the international market. In order to meet foreign competition, the industry has made significant $R \& D$ investments in the following areas [6]:

1. 1abor-saving and unmanned automated and robotic systems (radio controlled and amphibious bulldozers);

2. electronic systems to control mechanical functions (mechatronics);

3. energy-saving and anti-pollution engines;

4. "component type" and "module type" products; and

5. equipment for marine engineering projects. 
6. CONCLUSIONS

The construction industry is one of the key industries in Japan. The annual volume of revenues of the industry accounts for over 20 percent of the GNP of Japan. Recognizing the importance of the health of the construction industry to its economy, the Japanese government fosters the construction industry through government spending on public works projects during slump periods.

Over 50 large construction firms maintain research laboratories to maintain a favorable position in the very competitive construction market. The laboratories serve as a resource for solving immediate field problems; and, more importantly, they serve as a marketing tool. Research is an integral part of large construction firms. Benefits from investments in research laboratories by large construction firms are not 1 imited to the large firms a lone, but benefits a 180 accrue to many medium and small firms as research results are published or become known. As a result, construction technology in Japan has advanced.

The Japanese international market share of construction equipment has grown steadily. The Japanese construction equipment industry expects its exports to grow further in coming years. Having severed their ties with equipment manufacturing firms in the U.S. and Europe, Japanese firms will be relieved from restrictions on marketing territories. While energy-saving engines and automated equipment have given Japanese manufacturers a competitive edge in the international competition, manufacturers are moving ahead cautiously to avoid international trade frictions. 
The following summarize the findings in this report:

\section{Nature of Construction Industry}

- In terms of the GNP share, Japanese construction volume is about twice that of the U.S.

- The Japanese government makes a special effort to boost the construction industry by means of increased public works projects.

- In the international market, Japanese construction firms provide primarily engineering and contruction services, but the current situation is expected to change as they move into construction management.

- The volume of Japanese construction equipment manufacturing is second only to the U.S. at the present time. However, the gap is being narrowed rapidly through Japan's increased share of the world market.

\section{Construction Research and Development}

- The investment in construction $R$ \& $D$ by private and public sectors in Japan is about 0.1 percent of annua 1 billing of the construction industry.

- Industry, universities and government cooperate in construction research.

- Private construction $R$ \& D efforts contribute directly to productivity improvement.

- The Japanese government provides tax incentives for private contruction research.

- Private construction firms have active research in construction automation by applying industrial robotic technologies. 


\section{REFERENCES}

[1] Furukawa, 0., "The Japanese Construction Industry Today," The Overseas Construction Association of Japan, Tokyo, 1980.

[2] "Statistical Handbook of Japan, 1981," Statistical Bureau, Prime Minister's Office, Tokyo 162, Japan.

[3] MacAuley, R., "Economic Trends in the Construction Industry," Construction Review, May/June 1981, U.S. Department of Commerce, Washington, D.C.

[4] "1981-1982 Directory of Research Institutes in Japan," (in Japanese), Science and Technology Agency, Tokyo, Japan, 1982.

[5] "Japan Economic Yearbook 1981/1982," The Oriental Economist, Tokyo, Japan.

[6] Egoshi, H., "Construction Machinery Industry in the 1980's," Digest of Japanese Industry \& Technology, No. 144, Tokyo, Japan, 1980.

[7] Pulson, B. C., "Research in Japanese Construction Industry," Journal of the Construction Division, American Society of Civil Engineers, March 1980, New York. 
4. TITLE AND SUBTITLE

\section{CONSTRUCTION RESEARCH IN JAPAN}

\section{5. $A U T H O R(S)$}

H. S. Lew

6. PERFORMING ORGANIZATION (If joint or other than NBS, see in siructions)

7. Contract/Grant No.

NATIONAL BUREAU OF STANDARDS

DEPARTMENT OF COMMERCE

8. Type of Report \& Period Covered

WASHINGTON, D.C. 20234

9. SPONSORING ORGANIZATION NAME AND COMPLETE ADDRESS (Street, City, Stote, ZIP)

10. SUPPLEMENTARY NOTES

$\square$ Document describes a computer program; SF-185, FIPS Software Summary, is attached.

11. ABSTRACT (A 200-word or less factual summary of most significant information. If document includes a significant bibliography or literoture survey, mention it here)

The construction industry is one of the key industries in Japan. The annual volume of business of the industry accounts for over 20 percent of the GNP of Japan. Partially due to large investments in the public works projects by the Japanese Government, the industry maintained a steady growth during the past two decades. During this period of steady growth, many large construction firms established research laboratories to place themselves in a favorable position in the domestic, as well as international, construction market.

The construction machinery industry of Japan also grew steadily during the same period, and their share of the world market increased significantly. In order to meet foreign competition, the industry has also made significant investments in their $R \& D$ efforts.

This report examines the $R$ \& D efforts of Japan's construction and construction machinery industries and their trends.

12. KEY WORDS (Six to twelve entrles; alphabetical order; capltallze only proper names; and separate key words by semicolons) Construction; construction machinery; Japan; laboratories; research; R \& D

13. AVAILABILITY

[X] Unlimited

For Official DIstribution. Do Not Reiease to NTIS

Order From Superintendent of Documents, U.S. Government Printing Office, Washlngton, D.C. 20402.

$\$$ Order From Nationai Technical information Service (NTIS), Springfield, VA. 22161
14. NO. OF PRINTF.D PAGES

15. Price

$\$ 8.50$ 

